УДК 808.55:378.016]:[378.6:7](045)

ORCID ID: 0000-0001-5267-9658

Завальський Олександр Васильович, заслужений артист України, доцент кафедри сценічної мови. Київський національний

університет театру, кіно і телебачення імені І. К. Карпенка-Карого, Київ

Завальский Александр Васильевич, заслуженный артист Украины, доцент кафедры сценической речи. Киевский национальный

университет театра, кино и телевидения имени И. К. Карпенко-Карого, Киев

Oleksandr Zavalskyi, Honoured Artist of Ukraine, Associate Professor of the Stage Speech Department. Kyiv National

I. K. Karpenko-Karyi Theatre, Cinema and Television University, Kyiv

\title{
ОСОБЛИВОСТІ МОВНО-ГОЛОСОВОГО ТРЕНІНГУ НА СТАРШИХ КУРСАХ МИСТЕЦЬКИХ НАВЧАЛЬНИХ ЗАКЛАДІВ
}

\begin{abstract}
Анотація. У статті порушується проблема підготовки студентів старших курсів вищих творчих навчальних закладів щодо мовно-голосових навичок. Пропонуються експериментально перевірені та відпрацьовані на практиці методологічні напрями і вправи для відшліфування технічних якостей мовленнєвої майстерності, які разом з особливостями поєднання зовнішньої техніки з тренінгом внутрішньої психотехніки сприятимуть активізації підсвідомості та вдосконаленню сценічно-мовної дієвості акторського слова.
\end{abstract}

Ключові слова: сценічна мова, студенти старших курсів, мовно-голосовий тренінг, внутрішня психотехніка актора, зовнішня техніка актора, постановка дихання, дикція.

Постановка проблеми та иї актуальність. Студенти вищих мистецьких навчальних закладів, згідно $з$ навчальними планами, набувають мовних навичок лише впродовж перших двох років. На третьому-четвертому курсах безпосередня та цілеспрямована робота 3 викладачем щодо вдосконалення та поглиблення зовнішньої техніки актора (дихання, дикція, голос) - взагалі відсутня. Весь ухил у класі сценічної мови щодо оволодіння майстерністю актора зводиться до роботи над різножанровими творами, спрямованими на розкриття можливостей студентів як виконавців художніх творів (прозові уривки, робота над віршованою поемою, байкою, громадянською лірикою, інтимною лірикою, монологами з п’єс). А вся відповідальність за мовно-голосовий розвиток студента лягає виключно на його самостійну, усвідомлену індивідуальну роботу. На жаль, лише одиниці на цьому етапі навчання продовжують процес самовдосконалення та оволодіння дієвим словом. I тому художні керівники акторських курсів закидають викладачам сценічної мови, що старшокурсники працюють над читанням художніх творів, а не вдосконалюють зовнішню техніку (дихання, дикція, голос) для виконання ролей у дипломних виставах, що в майбутньому може стати проблемою для молодих акторів під час роботи в драматичних театрах і на знімальних майданчиках.

Mema cmammi - 3'ясувати та визначити особливості методологічних засад щодо поєднання зовнішньої техніки та внутрішньої психотехніки в класі сценічної мови для закріплення й поглиблення мовно-голосових навичок студентами 
старших курсів мистецьких навчальних закладів. У процесі дослідження використовувалися методи: аналітичний — для дослідження наявних теоретичних тлумачень мовно-голосового тренінгу та його практичного застосування; компаративний - у зіставленні та порівняльному аналізі практики застосування різних вправ; логіко-узагальнюючий - для підбиття підсумків дослідження та формулювання висновків.

Аналіз останніх досліджень і публікацій. Після ознайомлення 3 працями провідних майстрів сценічної мови Карасьова М. М.«Мистецтво художнього читання» (К., 1965 р.), Черкашина Р. О.«Художнє слово на сцені» (К., 1989 р.), Гладишевої А. О. «Сценічна мова» (К., 2007 р.), виявилося, що жоден автор не приділяє належної уваги мовно-голосовому тренінгу на старших курсах вищих мистецьких навчальних закладів. Але 3 огляду на сучасні вимоги театрального мистецтва поєднання постійного тренування технічних якостей мовлення — так званої зовнішньої техніки 3 тренінгом внутрішньої психотехніки - стало життєво необхідним. Саме тому, ознайомившись 3 науковими працями професора, завідувача кафедрою сценічної мови СПАТМ Галєндєєва В. M. і зацікавившись його методами викладання, я почав експериментувати, вдосконалюючи та поглиблюючи роботу з мовно-голосовим тренінгом на старших акторських курсах. За підтримки художнього керівника курсу та членів кафедри сценічної мови набутий досвід запроваджувався в роботі зі старшокурсниками упродовж трьох акторських випусків з 2009-го до 2019 року й на практиці довів доцільність і вмотивованість нововведень. Отож у статті пропонуються форми i методи систематизованого та методико-логічного вдосконалення мовленнєвої майстерності за допомогою мовно-голосового тренінгу.

Виклад основного матеріалу. Зазвичай у навчальних і методичних посібниках зі сценічної мови увага концентрується на перших (найвідповідальніших) етапах навчання: підготовці мовного апарату студентів до професійної роботи, постановці змішано-діафрагмального типу дихання та розмовного голосу, а також - на виправленні мовних недоліків. Уся інша робота приховується за поняттями «закріплення» та «розвиток». Найчастіше автори посібників зі сценічної мови рекомендують кількісні варіації в тренуванні. Приміром, на першому курсі, у класі сценічної мови, пропонують освоювати лише середину динамічного та звуковисотного діапазону, на другому — використовувати вже більшу його частину, на третьому-четвертому курсах — переходити до повного використання своїх голосових можливостей. Послідовність безперечно правильна. У театральній педагогіці процес взаємодії руху з голосом і мовою має розвиватися від простого - до складнішого.

На першому етапі навчання використовуються вправи, які допомагають звучанню й базуються на фізіологічних закономірностях тіла і голосу. Тіло та звук допомагають одне одному. Мета першого етапу — відчуття органічності та свободи.

На другому етапі - рух ускладнюється, активізується. Тіло не лише допомагає, а й «заважає» звучанню. Рух і тіло стають провокаторами «розумного, заощадливого» напруження. Воно тренує голос і робить вільне звучання навиком.

На третьому етапі навчання можливості тіла та голосу спрямовані на створення художнього сенсу, а рух і мова - на формування образу на сценічному майданчику. Але для тренування зазвичай пропонуються ті самі вправи, що й на першому курсі, втім, 3 іншими кількісними параметрами. Не враховується якісний розвиток творчої індивідуальності студента. Однак старшокурсники перебувають в особливому, зміненому ставленні до майбутньої професії. Це, звичайно, не міра учнівського ентузіазму, а складні духовні та психофізичні перебудови у свідомості й організмі молодої людини. Тобто студент за час навчання уже набув певний досвід, знання та навички, а йому пропонують - на кшталт «вчорашнього борщу» - старі способи опанування дієвим словом, яких вже недостатньо для його розвитку.

Чи не тому інтерес до тренувальних вправ на старших курсах найчастіше зникає, його витісняє жага «суто художньої» творчості? Досить часто наприкінці другого курсу мовно-голосове тренування взагалі сходить нанівець. І річ не лише в «настрої» студентів, а й у тому, що деякі викладачі вичерпують свої ресурси, необхідні для тренінгу. А більшість посібників зазвичай нічого конкретного не пропонують цьому розділу навчання (як виняток - книга Петрової А. Н. «Сценічна мова», М., 1981 р.). Тож так склалося, що в теорії методики сценічної мови залишається не освоєним цілий пласт цікавої та професійно-відповідальної роботи. Згадаймо висловлювання К. С. Станіславського, яке дає основу тренувальній роботі на старших акторських курсах: «... щоб зобразити найтонше, часто підсвідоме життя, треба володіти чутливим і розпрацьованим голосовим і тілесним апаратом». (Станіславський, 1954, т. 2, с. 26-27). Чудові та, на жаль, забуті думки. 
Що в них важливе для нас? По-перше, тренування техніки втілення (уся техніка мови) не лише не може скорочуватися 3 розвитком внутрішньої психотехніки, воно має розширюватися (особливо на старших акторських курсах), набуваючи складних і витончених форм. По-друге, у процесі розвитку та становлення артиста, тілесні (пластичні) та голосові навички мають нерозривно поєднуватися. По-третє, роль підсвідомості надзвичайно важлива не тільки у сфері переживання, а й у сфері втілення.

Тобто треба вчитися поєднувати тренування технічних якостей мовлення з тренінгом внутрішньої психотехніки, жодним чином не підмінюючи одне одним. Артист зобов'язаний дотримуватися цього ключового правила і під час виконання технічних вправ. Мабуть, це напучування тим, хто вважає, що тренування мовної та голосової техніки має відбуватися лише паралельно зростанню здібностей до переживання, не зачіпаючи «тонких душевних струн», не «перевантажуючи» апарат домінантним баченням, внутрішньою оцінкою, творчою увагою, пам'яттю почуттів, інтелектуальною волею, уявою - тобто усім арсеналом творчої обдарованості артиста.

Завдання, накреслені К. С. Станіславським, вимагають пошуку таких форм, які допомагали б удосконалювати способи тренування, відкриваючи шляхи до підсвідомості. Це неймовірно складна робота. Втім, конче важливо знайти можливі варіанти розв'язання цього питання.

Тренуватися треба багато, адже передумови для цього є. Тренінг заслуговує на те, щоб йому повністю приділялися групові заняття та частина індивідуальних. Кожне індивідуальне заняття зі студентами слід починати з розминки, пов'язаної 3 усвідомленою роботою над літературно-мистецьким твором. Вона може бути суто мовною або супроводжуватися музичним акомпанементом. Якщо йдеться про самостійну роботу студентів, то іiі інтенсивність залежить не лише від їхньої дисциплінованості, свідомості та захопленості, а й від того, наскільки несподівані та складні завдання поставлено перед ними викладачем.

Мовно-голосові тренування — це не лише «підтримка форми», а й обов' язкове надбання нових якостей і можливостей.

Одне 3 найважливіших завдань мовної техніки - досконале володіння системою резонаторів, перемикання регістрів в умовах мовного потоку, що ллється з необхідною швидкістю та інтенсивністю. Тут величезну роль відіграє м'язова свобода, володіння змішано-діафрагмальним диханням, тонкі внутрішні та слухові відчуття. Основи такої техніки закладаються на першому курсі навчання, де напрацьовується навичка резонувати за полегшених, «лабораторних» умов. Рухові диференціювання елементарні та досить прості. Ігровий елемент має «дитячий», «фізкультурний» характер. Будь-якої певної умови мовної техніки (сили, швидкості, модуляції) дотримуються окремо, у вигляді певної «моделі», не намагаючись тренувати навички плинно, динамічно, постійно змінюючи швидкість, інтенсивність і пластику.

Отже, конкретна пропозиція. Зберігаючи вірність ігровій основі мовно-голосового тренінгу, беремо в роботу вправу «Комар». Вона відома ще 3 першого курсу. Таку назву мала більш схематична вправа, під час виконання якої звуком «М» або «Н» намагалися імітувати дзижчання «комара» (вправа на пошук резонаторних відчуттів), який кружляє на певній відстані від виконавця.

Тепер «комар» стає промовистим - не «природним», а художнім, артистичним. Його політ втілюється (озвучується) швидкомовками, приміром: «Був собі паламар, та перепаламарився на маленьких перепаламаренят», «Був собі полукіпок, та переполукіпився на маленьких переполукіпенят», «Був собі цебер, та переполуцебрився на маленьких переполуцебренят», «Був собі короп, та переполукоропився на маленьких переполукоропенят».

Комар літає в пошуках здобичі, «кружляючи» в межах верхніх резонаторних ділянок. Тож потрібно, не втрачаючи його з поля зору, але не розмахуючи руками, ухилитися тілом від комара, який безперервно атакує та дзижчить. Суть цієї ігрової вправи полягає в тому, що студент одночасно має грати за двох - за нападника та за того, хто захищається. Нападає звуком (уявляючи кружляння над собою комара), а захищається тілом уникаючи нападу. Комар маневрує, наближається, відлітає, опускається, злітає. Його «дзижчання» то слабшає, то наростає, підвищується та знижується тонально, прискорюється, сповільнюється, «вібрує». Студент має розраховувати силу, швидкість, плавність, безперервність звукової лінії відповідно до того, як він «бачить» поведінку «нападника».

Тренуючись, прагнемо поступово розвивати й більшу потужність звучання, i значну швидкість мови при незмінній плавності ведення звуку та м'якому, «грайливому», пластичному тілі.

Плинна, «вібруюча» тілесна пластика створює передумови для ненапруженого звучання, хоч яким би потужним воно було. В основу багатьох 
вправ мовно-голосового тренінгу на старших акторських курсах треба закладати принцип «сила + м'якість». М'яке інтенсивне звучання слід доводити до підсвідомого рівня. Це один з педагогічних принципів вправи «Комар». Звичайно ж, під безперервним контролем викладача, а потім під самоконтролем, студент має працювати над бездоганною артикуляцією, чіткістю вимови.

«Комара» можна озвучувати різними швидкомовками: як легкими, що лягають на дикційно-голосове завдання (тридиять три кораблі лавірували-лавірували, лавірували-лавірували та не вилавірували), так і важкими, які вимагають поступового детального формування ( $y$ дворі трава, на траві дрова, раз дрова, два дрова, три дрова, дрова вздовж двору, дрова виир двору, під двором дрова, над двором дрова, щчо не вмістить двір дров, треба дрова видворити на дров'яний двір). Труднощі останнього тексту — у майже повній відсутності сонорних «М» та «Н». Під час виконання цієї вправи, треба все ж таки домагатися «дзижчання», тобто інтенсивного (як із сонорними) резонаторного звучання. Дихання у вправі добирається довільно, але так, щоб не розривати безперервний мовний ланцюжок.

Повернімося, однак, до принципу «сила + м'якість». Щодо м'якості, то йдеться про пластичність, плинність, «переливчастість» тілесних і дихальних голосових зусиль. М'якість - це спосіб голосової атаки, прагнення до інтенсивності, ба більше: потужності звучання.

Останнім часом у театральній педагогіці набувають поширення вправи для розвитку тілесної пластичності. Одна 3 них — «леопард» - привертає до себе увагу саме «кантиленністю» пластики. На сонечку розслаблено гріється леопард. Граційно, повільно, майже як у рапіді, він починає потягуватися, поступово розминаючи лапи, тулуб, шию. I, нарешті, напружується перед хижим стрибком. Під час виконання цієї вправи особлива увага приділяється гнучкості хребта, відсутності його прямої лінії в будь-якій фазі руху.

Корисно озвучити рухи «леопарда» будьяким текстом, що передбачає м'який розвиток і рішучий дієвий «кидок» (а отже і голосове зусилля) у фіналі. Ця вправа так само, на підсвідомому рівні, сприяє засвоєнню принципу «сила + м'якість».

Досі йшлося про суто індивідуальні вправи. Проте за жодних обставин не треба нехтувати можливістю тренуватись у парному чи груповому спілкуванні. Адже комунікативність - визначальна ознака мовного акту та один 3 найголовніших елементів школи К. С. Станіславського. На- приклад, можна використовувати таку мовно-голосову ансамблеву вправу: взяти речення «Еней був парубок моторний $і$ хлопець, хоч куди козак!» (Котляревський І. П.«Енеїда», Харків, 2015) і роздати його по слову дев' ятьом студентам. Вони мають стати в коло й одне за одним вимовляти слова, створюючи нерозривну фразу. Втім, ця фраза зазвучить лише після тривалих репетицій. Саме це й продемонструє труднощі, але водночас і важливість, групової взаємодії. Мета подібних вправ довести студентів до такого стану взаємодії, коли під час виконання будь-ким чогось неочікуваного, але достовірного - інші змогли б це підхопити та відповісти на тому ж психофізичному рівні. Оце i $\epsilon$ ансамблеве виконання, так звана — ансамблева творчість.

Такі мовно-голосові вправи необхідні студентам старших акторських курсів як синтез внутрішньої психотехніки та техніки втілення, коли 3 одного боку виникає пошук внутрішніх зав'язків між партнерами по грі, гранична концентрація творчої уваги, а з іншого — необхідність втілення авторського тексту в чіткій інтонаційно-смисловій і дикційній формі. Остання вимога обов'язкова для тренувальних занять зі сценічного мовлення.

Пропоную одну з варіацій цієї вправи. Група студентів сідає на підлогу, утворивши коло. Один 3 учасників мовно-голосового тренінгу повільно направляє по підлозі тенісний м'ячик до будь-кого 3 партнерів, починаючи говорити віршований текст, як от: «Тут їли різнії приправи і все 3 полив’яних мисок...» (Котляревський І. П.«Енеїда», Харків, 2015). Вірші вимовляються доти, доки партнер по колу не торкнеться рукою м'ячика, який підкотився до нього. Щойно відбудеться дотик, тепер уже інший студент має покотити м'ячик далі, миттєво підхопивши текст вірша та продовжуючи його, доки м'ячика не торкнеться наступний учасник вправи. Віршові рядки мають звучати безперервно. Втім, дотик може статися в середині рядка, на передостанньому слові тощо. Але кожен студент зобов'язаний підхопити темп, ритм, тональність, мелодійний хід партнера, а вже потім, якщо складеться, повернути хід розвитку тексту вірша по-своєму. У цій вправі, яка відточує мовленнєвий слух, тенісний м'ячик, що безупинно котиться, моделює розвиток наскрізної дії. Спочатку студентам буває важко виконувати це завдання. Вони починають «хитрувати», затримуючи м'ячик у руці, щоб продовженням дії виявився початок рядка, а не його кінець або середина. Однак поступово учасники тренінгу втягуються 
в гру, їх охоплює азарт, коли вдається «підхопити» партнера буквально на середині слова.

Простішою формою групової гри-імпровізації є відтворення цілого вірша по рядках, але сигналом до переключання стає перекидання м'ячика партнеру.

Для цієї мети можна взяти вірш Івана Франка «Якби знав я чари...» або вірш «Чому являєшся мені у сні...» (Франко, 3б. «Зів’яле листя», Львів, 2009. 160 с.), адже віршований розмір текстів (чотиристопний амфібрахій та чотиристопний ямб) задає певний темпоритм, зручний для роботи зі студентами старших курсів у мовно-голосовому тренажі. Звичайно (що дуже важливо), до початку гри, вірш треба докладно проаналізувати та вивчити напам'ять.

Не менш корисно під час виконання цих вправ скористатися ритмізованою прозою, скажімо, «Ярмарком» О. Вишні (Вишня, Вишневі усмішки. Заборонені твори. Харків, 2010. 384 с.). Учасники мають вишикуватися в шеренгу та «зчитувати» текст зі «стрічки телетайпа». Вона рухається спочатку повільно, а потім швидше й швидше, поступово перетворюючи текст мало не на швидкомовку. Стрічка переходить від одного партнера до іншого. Це досить емоційна та темпо-ритмічна вправа: у розслабленому самопочутті, не перейнявшись динамікою події, про яку йдеться в тексті, - студенти почнуть гальмувати, збиватися 3 ритму. Однак педагог має контролювати правильність виконання вправи, а також стежити за бездоганною дикційністю розповіді.

Ще одним різновидом тренування — $є$ тренінг до вистави. Слід зазначити на що треба звертати увагу, виконуючи необхідні вправи. Надважливим $\epsilon$ взаємопроникнення сфер внутрішньої психотехніки та перевтілення. Завдання педагога - довести володіння характерними особливостями мови до підсвідомого рівня та допомогти майстрам і режисерам підготувати студентів до роботи у виставі, залежно від жанру п'єси та режисерського бачення.

Як-от, для втілення жанру, розкриття теми та ідеї дипломної вистави за твором Ж.-Б. Мольєра «Тартюф, або Дурисвіт» (Мольєр. Повне зібрання творів в одному томі. М., 2009. с. 445-508), у класі сценічної мови студентам було запропоновано вправи, засновані на унікальній за смисловим i ритміко-синтаксичним наповненням репліці 3 фарсу Ж.-Б. Мольєра «Ревнощі Барбульє».

Для незміцнілої мовної техніки, для дихання, дикційної чіткості, голосових можливостей це стало неабияким випробуванням. Був ризик під виглядом «оголення наскрізної дії» все зім'яти, змазати, протріскотіти, промчати по тексту, залишаючи по собі звалище ненароджених і зажованих слів. Але завдяки проведеним тренінгам студентам було прищеплено поняття, що мистецтво дієвого слова полягає в тому, щоб не втрачаючи ні на мить головної ідеї, цілі, заради якої народжуються слова, зберегти високу культуру голосоведення та бездоганно чітку, філігранну дикцію.

Ось ця репліка:

«Отже, ти сприймаєш мене за людину, для якої гроші — це все, за користолюбця, за запроданця! Тож знай, приятелю, запропонуй ти мені гаманець, повний пістолів, який лежатиме у розкішній шкатулці, а шкатулка у дорогоцінному футлярі, а футляр у чудовій скриньці, а скринька у рідкісному поставці, а поставець у шикарній кімнаті, а кімната у найприємніших апартаментах, а апартаменти у дивному замку, а замок у незрівняній фортеці, а фортеця у знаменитому місті, а місто на родючому острові, а острів у найбагатшій провінції, а провінція у квітучій монархії, а монархія у цілому світі, - так ось, якби ти запропонував мені весь світ, де була б ця квітуча монархія, ця найбагатша провінція, цей родючий острів, це знамените місто, ця незрівняна фортеця, цей дивний замок, ці найприємніші апартаменти, ця шикарна кімната, цей рідкісний поставець, ця чудова скринька, цей дорогоцінний футляр, ця розкішна шкатулка, в якій лежав би гаманець повний пістолів, то мене це так само мало цікавило б, як твої гроші та як ти сам!!!» (Мольєр. Повне зібрання творів в одному томі. М., 2009. С. 6-14).

У наведеній репліці понад півтори сотні слів, які виражають досить просту думку. А можна було б обійтися десятком чи навіть меншою кількістю слів. Сказати, наприклад: «На біса мені ти та твої гроші?!». Що ж змушує мольєрівського персонажа вибухнути такою багатослівною промовою, в якій повністю відсутня будь-яка описовість? Вочевидь його розпирають почуття! Якщо конкретніше - ця гіперболізована (і закономірна саме для подібної жанрової природи) репліка $\epsilon$ результатом безперервного нагнітання ставлення до об'єкта та предмета висловлювання. Мольєрівський герой прагне скинути тягар свого ставлення до партнера й тому говорить так довго. Але ця удавана довгота - удавана лише для стороннього спостерігача, який не перейнявся почуттями, що вирують у душі героя фарсу. Проте для нього це зовсім не довго, а якраз стільки, скільки необхідно, щоб висловити всю повноту своєї зневаги, своєї уразливості та довести почуття власної пе- 
реваги. Ні про що інше в репліці не йдеться. Саме тому вона $€$ ідеальним зразком сценічної репліки, а не монологу.

Варто пояснити, чому під час підготовки до вистави було використано саме цю репліку. Мольєрівська фраза - це класична форма мовного періоду виняткового обсягу зі сходженням, переломом і спуском. Не так просто розподілити в ній дихання, намацати виразний мелодійний малюнок, продиктований змістом, а за майже неминучого зростання темпу - зберегти ідеальну дикційну чіткість. Вочевидь, впоратися з завданням можна, лише бездоганно володіючи звуковисотним, динамічним і темпо-ритмічним діапазоном. Саме тому фраза стала технологічним тренуванням, гігантською чистомовкою, а потім і швидкомовкою. Внаслідок чого видно, що форми тренінгу з єдиною словесною основою (мольєрівська репліка) практично невичерпні. Використання цієї репліки в дієвосмисловому завданні обов'язково повинно мати імпровізаційний характер, а освоєння іiі рухової структури може водночас використовуватися як одна із форм повсякденного «мовного туалету».

Можна сказати, що робота над Ж.Б.-Мольєром стала не лише полігоном, на якому випробовувався весь арсенал можливостей і навичок, а й величезним навчальним полем.

Виникає одвічне питання - тренуватися на тексті певного твору або ж на спеціально підібраному мовному матеріалі, який дає змогу досягти мети. Я за другий варіант рішення. До авторського тексту будь-що треба зберегти трепетне, «позатехнологічне» ставлення, залишити за ним недоторканну свіжість, первинність. Тренінг, задаючи механізми, життєдіяльність яких ми зобов'язані порушити, має впадати в основне русло роботи над твором, додаючи в нього специфічні та нові елементи, проте не захаращувати його надмірною технологічністю. Крім того, мовно-голосовий тренінг за всієї серйозності завдань, - справа неодмінно весела, пустотлива, навіть якщо він націлений на народження трагедії.

Форма «мовно-голосового тренінгу до вистави» особливо підвищує ініціативність і ентузіазм студентів старших курсів під час тренувальної роботи. Адже результати позначаться на ролі у виставі, перед наповненою глядачами залою.

Висновки. Особливості запропонованого у статті підходу до вирішення проблем мовно-голосового тренінгу на старших курсах мистецьких вищих навчальних закладів - у доцільності педагогічної тактики, відшліфованої упродовж десятирічного періоду викладацької практики, а саме: поєднання зовнішньої техніки (дихання, дикція, голос) 3 внутрішньою психотехнікою (бачення, оцінка, ставлення), із задіянням підсвідомості у творчому процесі народження дієвого слова. Це має здійснюватися щоразу особистісно, залежно від складу, рівня професійної підготовки студентського колективу та від завдань, що виникають під час роботи над дипломним репертуаром.

\section{Бібліографія}

Вишня, Остап. Вишневі усмішки. Заборонені твори. Харків: Книжковий Клуб «Клуб Сімейного Дозвілля», 2010. $384 \mathrm{c}$.

Галендеев, В. Н. Не только о сиенической речи. Санкт-Петербург: СПбГАТИ, 2006. 384 с.

Гладишева, А. О. Сиенічна мова. Київ: Червона рута-турс, 2007. $264 \mathrm{c}$.

Карасьов, М.М. Мистецтво художнього читання. Київ: Мистеитво, 1965. $146 \mathrm{c.}$

Котляревський, І. П. Енеїда. Харків: Видавничий дім «Школа», 2015. $248 \mathrm{c}$.

Мольер, Ж.-Б. Полное собрание сочинений в одном томе. Москва: Альфа-книга, 2009. 1231 с.

Петрова, А. Н. Сценическая речь. Москва: Искусство, 1981. $96 \mathrm{c}$.

Станиславский, К. С. Собрание сочинений в восьми томах. Москва: Искусство, 1954. Т. 2, с. 26-27.

Франко, І. Я. Збірка «Зів’яле листя». Львів: Літопис, 2009. $160 \mathrm{c}$.

Черкашин, Р. О. Художнє слово на сиені. Киї: Вища школа, 1989. $324 \mathrm{c}$

\section{References}

Vyshnia, O. (2010). Vyshnevi usmishky. Zaboroneni tvory [Vyshnevi usmishky. Forbidden Works], Kharkiv. 384 p. [in Ukrainian]

Galendeev, V. N., (2006). Ne tolko o stsenicheskoy rechi [Not just about stage speech]. St. Petersburg: Sankt-Peterburgskaya akademiya teatralnogo iskusstva, 2006. 384 p. [in Russian]

Hladysheva, A. O. (2007). Stsenichna mova [Stage Speech]. Kyiv. 264 p. [in Ukrainian]

Karasov, M. M. (1965). Mystetstvo khudozhnoho chytannia [The Art of Artistic Reading]. Mystetstvo.146 p. [in Ukrainian]

Kotliarevskyi, I. P. (2015). Eneida [Eneida], Kharkiv. 248 p. [in Ukrainian]

Moliere, J.-B. (2009). Polnoe sobranye sochynenyi v odnom tome [The complete works in one volume], Moscow. 1231 p. [in Russian]

Petrova, A. N. (1981). Stcenicheckaia rech [Stage Speech]. Moskva: Iskusstvo 96 p. [in Russian]

Stanislavskyi, K. S. (1954). Sobranie sochinenii v vosmi tomakh [Collected Works in Eight Volumes] (Vol. 2). Moskva: Iskusstvo. P. 26-27. [in Russian]

Franko, I. Ya. (2009). Zbirka «Ziviale lystia» [«Withered Leaves»]. Lviv. 160 p. [in Ukrainian]

Cherkashyn, R. O. (1989). «Khudozhnie slovo na stseni» [Artistic Word on Stage]. Kyiv. 324 p. [in Ukrainian] 


\section{Oleksandr Zavalskyi}

\section{Language and Voice Training Course for senior courses of art educational institutions}

Abstract. The article deals with the issue of senior students of higher creative educational institutions training, exactly the issue of their speech and voice skills building.

The article offers experimentally tested and practical methodological directions and exercises for honing of speech skills' technical qualities, which, together with the peculiarities of combining external technique with internal psychotechnics training, will positively influence on subconscious mind activating and stagespeech efficiency of the actor's word.

Keywords: stage speech, senior students, speech and voice training, internal psychotechnics of the actor, external technique of the actor, setting of breath, diction.

\section{Завальский Александр Васильевич}

\section{Особенности речево-голосового тренинга на старших курсах учебных заведений культуры}

Аннотация. В статье затрагивается проблема подготовки студентов старших курсов высших творческих учебных заведений касательно голосо-речевых навыков. Предлагаются экспериментально проверенные и отработанные на практике методологические направления и упражнения для оттачивания технических качеств речевого мастерства, которые вместе с особенностями сочетания внешней техники и тренингом внутренней психотехники будут способствовать активизации подсознания и усовершенствованию сценической речевой действенности актёрского слова.

Ключевые слова: сценическая речь, студенты старших курсов, голосо-речевой тренинг, внутренняя психотехника актёра, внешняя техника актёра, постановка дыхания, дикция. 